Article

\title{
Social Sciences, Art and Physical Activity in Leisure Environments. An Inter-Disciplinary Project for Teacher Training
}

\author{
María Belén San Pedro Veledo ${ }^{1, *(\mathbb{D})}$, Inés López Manrique ${ }^{1}$, Inés Fombella Coto ${ }^{1}$ (D), \\ Yolanda del Cura González ${ }^{1}$, Beatriz Sánchez Martínez ${ }^{1}$ and Ana Isabel Álvarez González ${ }^{2}$ \\ 1 Department of Education Sciences, University of Oviedo, 33005 Oviedo, Spain; lopezines@uniovi.es (I.L.M.); \\ fombellaines@uniovi.es (I.F.C.); curayolanda@uniovi.es (Y.d.C.G.); bsanchez@uniovi.es (B.S.M.) \\ 2 Department of English, French and German Philology, University of Oviedo, 33011 Oviedo, Spain; \\ anabel@uniovi.es \\ * Correspondence: pedromaria@uniovi.es; Tel.: +34-985-102-881
}

Received: 9 May 2018; Accepted: 28 May 2018; Published: 29 May 2018

\begin{abstract}
Factors such as social change and increasing urbanization processes in the early years of the 21st century have caused a reduction in the amount of time that children devote to leisure activities in the open-air, resulting in more sedentary lifestyles than children in previous decades. An education in healthy habits from early ages to increase children's physical and mental well-being together with their level of cultural knowledge contributes to the acquisition of a Leisure Culture that allows children to perceive the close environment as a scene for learning and enjoyment. It is thus be necessary for schools to foster pedagogical experiences, taking the physical and cultural environment as teaching resources. An innovation project is proposed which will be implemented with 25 university students from the School of Teacher Training and Education at the University of Oviedo (Oviedo, Spain). The project will consist of the proposal of educational itineraries through the city of Oviedo and Mount Naranco. As teachers-to-be, students must combine knowledge of the related areas and generate inter-disciplinary activities throughout the routes that will foster respect for the environment and leisure based on culture and physical activity, attitudes that they will transmit to their own students in the future.
\end{abstract}

Keywords: education; teacher training; interdisciplinary; social sciences; art; physical education; leisure culture; educational itineraries

\section{Introduction}

Leisure time describes time free from any compulsory activity, be it professional, social or family-related. According to González [1], leisure must be understood as a human experience that positively contributes to one's health and well-being, both physical and mental, and also a means for personal and social development. Education in creative leisure-by integrating it into the curricula through physical, mental and emotional activities-is crucial to that well-being. The same author provided a classification of leisure activities: culture-related, practical-productive, and social and physical activities. Thus, leisure appears to be a key concept for education, learning and health. Organizing leisure -time is a key factor in the development of the young, and it is therefore necessary to build opportunities for correct usage of spare time and the development of-among others-cultural, artistic and physical values that will foster socialization and self-esteem [2]. Some studies have indicated that leisure, understood as students' quality of life, is often unsatisfactory due to a lack of related abilities and capacities [3]. This has resulted in an increasing number of universities offering 
courses and study programmes oriented toward the development of leisure activities among their students. Such programmes have had good results in, among other factors, active learning, self-esteem and physical and mental health $[4,5]$. Sport and cultural activities are often included as part of leisure time, and, although they are often analyzed independently, a significant correlation has been established between sport and participation in cultural activities, which appear to be complementary activities [6]. Even though open-air activities are often related to sport practice in places that have not suffered great changes due to human activities, the natural environment also offers cultural settings which result from the interaction between humans and the physical world. Doistua and Ried, in their work on the impact of leisure time activities on the environment, pointed to the physical, emotional and cognitive benefits of activities that combine natural and cultural aspects [7]. Hence, the concept of Educational Leisure Settings (ELS), leisure time areas that may include museums, tourist trails and archaeological sites is gaining relevance, as these activities have a vast didactic potential.

Learning in ELS results in experiences that merge entertainment and education [8]. Natural and rural settings and historical and/or cultural monuments are gaining relevance when it comes to deciding on possible destinations for trips and guided tours, and are increasingly being enhanced by local communities to attract tourists [9]. Schools must take the role of coordinators of educational and leisure experiences, as a new way to promote knowledge with the aid of non-formal setting-based learning $[10,11]$.

A possible way for the introduction of Leisure Culture in school settings, to achieve the acquisition of correct habits for mental and physical well-being, is through outdoor learning. The "outdoors" is a physical and ideological space where people interact with the environment, but it is also a very important scenario for learning and leisure [12]. It is well-known that contact with the open-air not only has a positive impact on children's physical and psychological health, but also on their interactions and social networks, helping to develop creative potential and mental, linguistic and motor abilities $[13,14]$. However, social changes in the 21st century and increasing urbanization processes have affected the amount of time that children devote to open-air activities, leading to more sedentary lifestyles that are disconnected from the natural environment $[15,16]$. An experience that took place in Vermont, USA, related the absence of open-air activities among children to apathy toward the environment and a separation from the natural world. Thus, it is necessary for teachers to make open-air activities part of the curriculum [17]. A good way to include educational experiences in this field is by using the city [18-20] or the close environment as didactic resources. Several areas of knowledge, like physical education $[21,22]$ or natural and experimental sciences $[11,23,24]$ already occasionally link leisure and open-air learning, and have been associated with good results in the acquisition of knowledge, self-efficiency and environmental consciousness. Several experiences and studies on open-air learning programmes related to environmental education and sustainability have resulted in achievement and/or improvement in motivation and enjoyment, thus promoting social abilities and positive attitudes toward the environment [25-29]. Results obtained through these studies have shown that it is not only students who benefit from such programmes, as teachers also gain sensitivity towards the environment and consider this form of learning to have a greater impact than learning carried out indoors. $[30,31]$. Nevertheless, the same studies point to a lack of time and sufficient budgets, together with officially imposed curriculums as the main drawbacks for these activities. It is therefore relevant to insist on training teachers in using the close environment as a didactic space, at no extra cost for students or schools, using spare time as a means of teaching and learning.

Affeldt et al. pointed out that since current society is increasingly focusing on sustainable development as a backbone of human activities, it is necessary, within the debate on sustainability, to connect teaching with real situations, to foster significant learnings that motivate students to have responsible attitudes form early years [32]. They also suggested that observing the impacts of human activities on an individual's own environment, through outdoor activities in leisure time, may contribute to the acquisition of a larger and more sustainable environmental awareness. 
When schools are connected to their surroundings, students may apply their knowledge to authentic problems, thus contributing to community life [33]. At a time when communities are increasingly reacting toward globalization by enhancing their local surroundings and patrimony, it seems accurate for curriculums to include experiences that will bring students closer to their own culture by means of open-air activities [34]. However, Cebrián and Junyent [35], researched the perceptions of competence in education for sustainable development by teachers-to-be and indicated that prospective teachers give priority to the acquisition of knowledge and skills in the area of natural sciences, leaving out the promotion of positive attitudes and values related to sustainability. This shows the relevance of promoting teacher training didactic programmes with an interdisciplinary approach to surrounding areas, landscapes and the environment that will also foster cultural and physical activity-related values.

The present paper describes a pilot innovation programme, titled "Social Sciences, Art and Physical Education in Leisure Settings" (Figure 1). The project, which will be conducted with students of Education from the University of Oviedo, aims to promote experience-based interdisciplinary work across different knowledge areas to promote relationships between people and their natural, spatial and cultural environments, in order to arouse ethical and critical consciousness towards them. To this aim, students will take part in interdisciplinary didactic itineraries in the nearby environment.

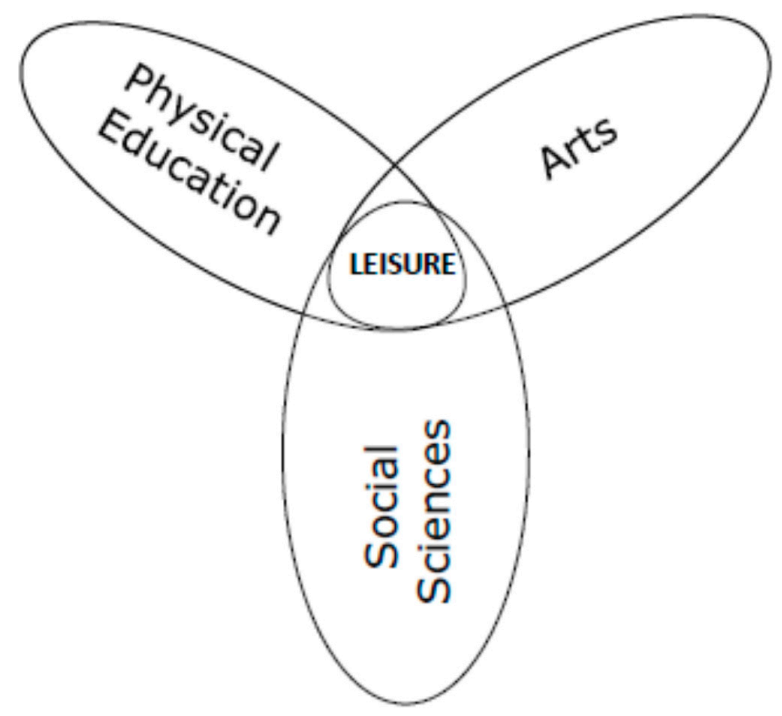

Figure 1. Social sciences, art and physical education as connecting links for leisure culture (elaborated by the authors).

\section{Project Description}

\subsection{Background}

This project arose out of two questions: (1) Are new generations being trained in the abilities required for significant usage of leisure time? (2) Do teachers get training in order to carry out these tasks in schools? Answers might be found among university teachers and their everyday practices. Despite the existence of the above-mentioned investigations on the appropriateness of introducing leisure culture and the positive results obtained, current curricula are seriously lacking at this point. It is therefore necessary to provide education students with knowledge and skills that they can transversally unify and transmit to their own students in the future. To this aim, interdisciplinary practice through leisure and outdoor activities is presented in this project as an opportunity. 


\subsection{Objectives and Participants}

The objective of this study is to enable teachers-to-be to plan interdisciplinary projects for leisure time, using the close environment as a link between physical activity, social sciences and art.

The project has been designed to be implemented with 25 participants, all of them students from the School of Teacher Training and Education at the University of Oviedo (Spain). Participation in the activity will be voluntary and will take place in semesters 4 or 6 . Students will take different subjects in the fields covered in the project: physical education, art and social sciences.

\subsection{Setting}

The settings chosen for the project are the Naranco Range (best known as Mount Naranco) and the Oviedo river basin, located in the Principality of Asturias, in Northern Spain. Mount Naranco is a $5 \mathrm{~km}$ long, east to west mountain range, from the parish of Villaperi to Brañes, where it turns north at the Llubrió Range. Its origin is a paleozoic block, formed by rocks from the Superior Devonian period on the Southern side and mountain limestone from the Carboniferous period on the Northern and Western sides. It is a watershed between the Maxuca and Nora rivers. The Southern gradient is abrupt, whereas that to the north shows a greater contrast due to fluvial erosion, with a gentler topography towards the Nora river. The Oviedo river basin is located between the Naranco Range and the Grandota Range, which is a watershed for the Nalón and Nora-Gafu rivers. It is a depression with soft slopes, excepting for in the east and west, and is the site of the city of Oviedo.

Lillo, set on Mount Naranco, is an internationally well-known site, as it contains two of the most widely renowned pre-Romanesque monuments, San Miguel de Lillo and Santa María del Naranco, which were built under the rule of King Ramiro I in the first half of the 9th century A.D. and were originally part of a palace complex together with some other constructions. Both buildings, which have been declared UNESCO "Human Heritage" sites, must be related to others built in the city of Oviedo during the period of the Asturian Monarchy (8-9th centuries A.D.), among which the church of San Julián de los Prados, the Sacred Chamber in the Cathedral and the Foncalada fountain stand out.

The cultural richness of Mount Naranco is not, however, limited to the pre-Romanesque buildings, since the landscape, which resulted from diachronic development, shows innumerable traces left by humans from antiquity to the present time. The range is marked out by seven strategic fortifications aimed at controlling routes in Roman and Medieval times: Monte Alto, located $312 \mathrm{~m}$ high, in La Cruz, which was destroyed due to the growth of the city of Oviedo; La Cogolla, in Fitoria (270 m); Picu Castiello de Cuyences (205 m); Picu Castiello in Llugarín placed $200 \mathrm{~m}$ high, which was destroyed due to the activities of a nearby quarry; Picu Castiello de Quintana (420 m); Castiello de Llubrió (240 m); and Castiello de Brañes $(230 \mathrm{~m})$. Some of the fortifications that have been preserved to present times are affected or under pressure by urban growth and quarries.

Of no lesser importance than these signs of archeological heritage are those of an ethnographical kind, such as bridges, mills, public washhouses and fountains, together with various caves and military constructions bound to the Spanish Civil War.

On the other hand, it must be noted that the setting offers numerous possibilities for physical activities, with walking and cycling trails, recreation areas and parks.

Taking the opportunity afforded by the didactic and leisure possibilities of Mount Naranco, four interdisciplinary learning itineraries, to be completed by education students at the University of Oviedo, have been proposed. Based on a holistic approach to heritage, the proposed itineraries conjugate different historical, ethnographic and artistic elements through routes that involve physical activity. Two of the routes will take place on the mountain itself, in a semirural environment along the Eastern and Western sides. Two other routes will originate in the city of Oviedo and continue to the pre-Romanesque monuments on the range. The proposed out-and-back walking routes will take from four to six hours. The routes are as follows: 
1. Western route: departure takes place in Vallobín, a quarter in Oviedo, and the destination is Castiello de Brañes. Throughout the route, participants may observe various rural areas, the Castiello de Llubrió and Castiello de Brañes forts and traditional washhouses.

2. Eastern route: departs from the quarter of Villamejil and reaches fort Picu Castiello de Quintana. Relevant landmarks, together with the fort itself, are La Cogolla, Picu Castiello de Cuyences and the original site of the no longer existing Picu San Pedro. Numerous other traditional buildings and the military camp of Llugarín are also part of the route.

3. Santullano route: departing from the pre-Romanesque church of San Julián de los Prados, it reaches Mout Naranco after passing through Montealto, where the previously mentioned forts are located. The route ends in Lillo, by the pre-Romanesque buildings.

4. Cathedral route: leaves from Cathedral Square, which is located close to different places of interest, such as the Fine Arts Museum, the Holy Chamber, the Archaeological Museum, the Chapel of the Balesquida and the Palace of Marquis San Feliz. It continues to La Escandalera Square and Uría Street, the main commercial hub of the city, with numerous instances of residential architecture, such as La Casa del Termómetro, La Jirafa, La Casa del Cuitu, La Casa Blanca and unique buildings like the Campoamor Theatre. The route continues up Monumentos Avenue and reaches the pre-Romanesque church of San Miguel de Lillo. The main characteristic of this route is that it passes through the historical city centre and reaches the site of the pre-Romanesque buildings, intersecting with other trails of great social and cultural interest, such as the Way of Saint James (Camino de Santiago) and the Clarín Trail, based on Clarín's best-known novel, La Regenta.

\subsection{Knowledge Areas Involved}

Three subject areas in the Spanish official curriculum were selected for this project: physical education, art and social science.

Tourism is the quintessential link between social science and leisure [9], as historical and archaeological sites relate to certain landscapes and given geographical spaces. There are many who consider the range of cultural activities available when choosing tourist and holiday destinations. This cultural tourism appeals to visitors, be it on the historical side (museums, monuments and historic city centres), the ethnographic side (eco-museums and traditional settlements) or the archaeological side.

Getting in contact with the past has an influence on people who are attracted to different places and moments where people lived whose social parameters were different from those of present times. First-hand observations of human manifestations from the past is often an aid in downplaying present times and in imagining oneself in other, different contexts. Some studies have indicated that a preference for this type of tourism is linked to very highly-educated individuals [36], though cultural tourism and leisure are gaining relevance among people with very different profiles. In fact, in some European cities with protected historic city centres, there is increasing debate as to the appropriateness of continuing to appeal to foreign visitors and the impact this may have on heritage and on the local population [37]. However, studies also point at the positive impact that tourism related to archaeological sites, often located in rural areas, may have on the local population, as it positively contributes to social and economic improvement [38,39]. There is usually a social component in these activities, involving interaction between people and different cultures, thus promoting essential values in shaping democratic, responsible and plural citizenship.

Geography must not be underrated in proposals like the one in this paper and is nowadays also integrated in the tourist industry by means of geolocation mobile applications, such as Geocaching [40], which may be considered as a treasure hunt activity that has been adapted to the 21st century. Users create an account on the official website and may use the app to find geocaches (containers or small boxes left at a place by other users) anywhere on Earth [41]. Users then report on their experience online. There are, at the moment, millions of geocaches all over the world, often placed in city centres 
and other areas of interest related to them, so, by means of geocache tracing activities, visits to cultural settings may be combined with physical activity.

Open-air activities have been part of physical education (PE) ever since it became a school subject and are one of the content areas students show more interest for. This may be explained with reference to Self-Determination Theory (SDT) [42], which points to intrinsic motivation as the factor that initiates and maintains the wish to perform an activity. Within the SDT framework, the Theory of Basic Psychological Needs points at three needs that must be met in order to favour intrinsic motivation: competence, autonomy and relation. It is in this sense that the characteristics of the activities proposed (freedom, enjoyment, emotion, social relationships, challenge, adventure, etc.) may meet those needs and render them as optimal tools for leisure education.

Self-Determination Theory investigates to what extent human behaviour is self-determined; that is, to what extent people can regulate their own behaviour and act reflexively and voluntarily. It also emphasizes the importance of the evolution of internal human resources for the development of personality and self-regulated behaviour. It considers people to be active organisms with innate tendencies toward psychological growth and development, oriented towards learning and mastering new abilities that are vital, self-motivated and out of curiosity. This is to say that intrinsically motivated people are naturally prone to assimilation, exploration and learning, even though adequate conditions are required in order to keep and broaden those tendencies [42]. On top of personal dispositional factors in behavioural development, situational factors must be added that will eventually tilt the scales towards either personal development or alienation and passivity.

This project aims to create educational settings that consider this initial motivation and promote situations that maintain and increase intrinsic motivation. It thus responds to an autotelic conception of leisure, which is defined as an attitude to search for experiences and relationships oriented towards satisfaction, creativity and freedom of choice [43]. It is therefore an active kind of leisure, which proposes leisure activities that will promote personal development.

It is a fact nowadays that children do not spend a sufficient amount of time doing open-air activities [44], so schools are promoting programmes that will bring them closer to the positive experiences that nature may bring about. For many years, PE teachers have had specific training in planning and performing these activities, though with the new curricula in teacher training (after the implementation of the so-called Bolonia Plan), this specificity is no longer present. However, proposals are being made by PE professionals that go beyond mere physical activity. Interdisciplinary approaches, like that by Bochonek [45], claim that educational tasks that do not include touristic activities as aids to the educational process should not be proposed by contemporary schools. The programme promoted by this author affected five educational spheres: education for adventure and tourism, physical education, education in regional cultural heritage, ecological education and social-moral education. The results from the study showed increased participation in active forms of tourism by young participants.

Active leisure implies the development of physical practice habits, but also sensitization and the development of a critical conscience toward social and environmental surroundings. Awareness of membership in a society or its environment may cause adaptation or denial [46].

It is therefore necessary to encourage students to get hold of the environment through direct contact.

Experiences are non-transferable and, especially when it comes to the natural environment, impossible to reproduce in different settings without a loss of their educational potential. Open-air physical activities foster a feeling of being connected to the environment and a sense of personal welfare through internalization of the experience [47]. All in all, in PE, we point to values that are linked to educational, social and health matters, promoting practice habits that are oriented towards autotelic leisure, which favours intrinsic motivation, since current society is increasingly concerned with mental and physical health. 
Jarvis et al. have linked the decline of mental health among children to a reduction in the amount of opportunities to participate in open-air games [48]. In addition, the rise in obesity has caused urgent demand for programmes that increase physical activity. Several theories account for the boost in obesity rates among the young over the past decades. Despite the growing number of activities proposed, such as after-school sport activities, children's spare time has been reduced [49], a dual situation that has necessarily been taken into of account in the current project. On one hand, the freedom of election must be promoted in order to meet the basic psychological need for autonomy and to promote the development of intrinsic motivation. On the other hand, the curricular objective of building physical practice habits among students calls for the development of individuality and personal time management. Fostering creativity among students by promoting mastery climate [50] that considers age-related differences in interests and motivations [51] is a priority in the development of programmes like the one being presented. Thus, interventions that keep with the interests of school children tend to include open-air exercise and physical activities to be performed in the natural environment in order to favour longer daily practice [52].

Sustainability is an integrating concept, and so it is addressed in this paper. However, guidelines must be established that will specify actions to be taken in order for the model of human development to be sustainable in regard to ecological diversity and environmental resources. Among the principles of sustainable sport proposed by Fraile [53], that of "qualitative excellence" points at a model of physical activity and sport that is based on the quality of the experience and on the improvement of environmental conditions.

The proposed programme responds to this principle of qualitative excellence in that it is based on life experiences, and is accessible and adapted to the students, thus meeting the need for individual competence, decision-making and the development of social relationships. As for "activity for life", it has been pointed out that the proposal takes an autotelic leisure perspective, addressed at personal growth in accordance with STD principles.

A third principle related to sustainable physical activity is the "principle of reparation". Activities aimed at "repairing" polluted environments will be part of the proposal, thus favouring sensitization by focusing and reflecting on certain unethical behaviours.

Finally, we must point to some aspects of the principle of "sport diversity", which focuses on having a multiplicity of sport practice opportunities in order to avoid increasing sport dropouts among teenagers [54-56]. It is indeed characteristic of open-air physical activities that they allow for multiple motor implementations which allow for performance in different environments and use materials that are in constant evolution towards higher performance and, most of the time, towards more enjoyable practice. They bring into play all kinds of motor abilities and skills, which are, in principle, not developed towards a competitive aim. Behind these activities is a philosophy of adaptation to every level of physical condition and capacity. In the present project, motricity is an entrance gate to the environment and the backbone of a pedagogical proposal with different areas. Walking, although a means in itself (trekking along the routes) is also an end, as it immediately brings benefits at mental and physical levels. In addition, contents from the different areas are involved, resulting in enriching experiences capable of connecting students to the environment and fostering metacognitive knowledge, a process that makes it necessary to observe students' previous knowledge, together with their previous beliefs and motor experiences, in order to set up a programme based on significance and functionality.

An objective set in the programme is to arouse students' interest for what surrounds them and for what they see on the way. PE will put focus on aspects such as necessary hiking techniques for different types of soil or slopes; adequate pace according to one's physical condition, age or the distance to be covered; energy use and the need for recovery; how to read the instruments required for orientation, together with reading natural signs; having a good rapport with "travel companions" and showing respect for them; risk and safety; and emotions. This is the direction that any project must take in order to attain the best results. Positive sensations towards the environment must be promoted among 
participating students, enhancing quiet observation of what they reach with every step, using all five senses to capture moments, and increasing sensitivity towards the environment. This is precisely what environmental education is about: knowing, respecting, loving, and preserving. Throughout a process that starts by getting to know the natural environment, individuals will make bonds with nature that will arise from respect for its diversity and lead to love for nature and a wish for its preservation.

Art is a cultural phenomenon and product, together with aesthetic and creative life experiences [57]. Artistic experiences in current society have been encompassed in so-called leisure time, the time free from labour activity that allows people to enjoy themselves, learn and improve while leading a given lifestyle. Both physical and artistic activities are carried out in this leisure context by people of different ages and diverse social, cultural and economic backgrounds. They foster well-being, promote the development of spatial intelligence, promote kinetic body intelligence and ease the creation of bonds with the environment and surrounding people [58].

Although scarcely present in current teaching practice, the development of curricular content in compulsory education through teaching architecture is a positive contribution towards the development of different competences among students and is acknowledged as a tool of a great interdisciplinary power, especially for the acquisition of the geometrical concepts included in the primary education curriculum through art [59]. Knowledge of the immediate built environment, where everyday activities take place, where most personal and professional life is spent, and where learning processes and emotional and cognitive development are set, is taken to be crucial for a better understanding of the place we live in [60]. In addition, it makes a positive contribution to significant learning, one that is linked to a student's own environment, thus avoiding out-of-context learning [61].

This view may also apply to leisure, since travelling and getting to know new places-not only the faraway ones, but also close and relatively well-known areas-is one of the main leisure-time activities. Getting to know certain keystones relating to architecture and urbanism will turn any trip or visit to a place, be it new or previously-known, into a much richer experience, allowing students to discover the didactic possibilities of the built environment. As stated by Romañá [61], architecture and its spaces may be taken as a way into teaching. The shape of towns and cities, their surroundings, the sectioning of streets, the scale and proportions of public spaces, the existence of open spaces in front of certain buildings, etc., are all elements of urban structure and influence our lives, the way we move around, our behavior and the way we perceive the environment. Although perception is different in children and adults and is primarily related to the activities performed at each place [62], educational actions like the one being proposed will nurture the perception of certain areas and places in the close environment and have a positive impact on capacities like orientation or spatial intelligence [63].

As for architecture and visual arts, providing students with necessary keystones for the analysis of the artistic work and the buildings they observe and those they use and live in will give them a better knowledge of the close physical environment, together with the capacity to analyze, compare and relate reality to what they have learnt in theoretical ways. Furthermore, teaching architecture aids students in attaining a better understanding of the space around, a space that includes the present, the past and the future [60].

All these built elements, together with the natural spaces that are also included in the project (parks, trails, etc.) will help students to understand and assimilate the influence of human beings upon the territory and the different traces left behind throughout history, introducing sustainability as an indispensable quality for responsible development.

\subsection{Development of the Project}

The project will aim to make learning part of students' leisure time. Thus, content related to the different areas involved will go further from the school setting, contributing to better consolidation and, given adequate coordination among teachers, will not require more teaching hours, nor changes or adaptations to current curricula. 
For two weeks, participating students will be shown, during ordinary classes of the subjects involved in the project, aspects related to what can be found along the different routes. Many of the aspects under consideration may be taken as cross-cutting, as is the case with those related to spatial conceptions and capacities, orientation and visual analysis.

In teaching methods for the social sciences classes, the itineraries will be interconnected with the syllabus, with the concept of landscape in the European Landscape Convection held in Florence in 2000 as a connecting link: an area, as perceived by people, whose character is the result of the action and interaction of natural and/or human factors (Article 1) [64].

Mount Naranco is set on a natural environment that has been modified by humans over centuries, and it therefore holds traces of human action from every period. It is for this reason that students must acquire the tools required to be able to "read" the landscape, and interpret the stories each "layer" tells of a given period, in order to get closer to each age.

Studying the landscape of Mount Naranco will also allow for on-site examples of balance among different spatial scales at different moments in time, ultimately interrelating the present, the past and the future of the environment and society through a number of questions: How are the populated areas now? How did they used to be? What is/was their economic outcome? How do/did inhabitants conceive their space and what is/was their world view? What do they their traditions tell about the past?

The approach in the present proposal will also allow for a forward-looking projection, observing the current landscape, analyzing human impact on the range and finding alternatives to bring about a sustainable landscape. Even the analysis of the now disappeared fortifications may be used to a didactic aim. Mental reconstruction of elements that can no longer be observed implies an intellectual activity that blends previously-received information, creativity and imagination, thus arousing consciousness about the protection of still preserved, though jeopardized, elements. All these issues will be dealt with in class, prior to the field trips.

Specific competences in teacher training point at physical education as an area that must train professionals that are capable of fostering lifelong participation in sport activities among the student population [65]. It is, therefore, be more adequate to refer to physical activities and not only to sport, as is mentioned in the learning outcomes for the related subject areas. Similarly, reference is made to the need for the comprehensive development of students to be promoted, particularly in regard to cultural, social and personal development. This holistic concept of physical education is nowadays acknowledged in the legal regulations framing curricula.

The curriculum for physical education points at outdoor spaces away from school as adequate for learning, highlighting the usage of the natural and urban environment and linking physical activity to the development of healthy habits in leisure and open-air activities. In addition, it points at these activities as being adequate for developing values associated with environmental care and preservation [66]. To this aim, content involving physical activities in the natural environment, or "outdoors" from habitual school settings, are regarded as nurturing resources. Nevertheless, the complexity of implementing these activities, together with the need for optimization, makes a multidisciplinary approach to field trips the best approach possible.

Prior to the outings themselves, several preliminary issues may be tackled. The physical activity required implies taking hikes over different types of terrain and slopes. Such a practice started in France in the previous century, resulting from a half-sport, half-tourism need to spend leisure time using one's own means to complete a route on foot [67]. A motto among hikers is "learning to see". Our interdisciplinary proposal elaborates on that issue, as it provides students with tools to lead them to a double process, inside-out and outside-in, with respect for individual freedom of interpretation of facts while exchanging views with classmates under the supervision of a guiding teacher, who makes use of his/her creativity and pedagogical knowledge. As for physiological benefits, being a moderate toning activity, it will increase functional capacities and the efficiency of organic systems. 
Just as in any other similar project, it is relevant for participating students to follow the guidelines provided, not only during the outing itself, but also at previous and later stages. During the lessons preceding the trip, students must get to know how physically demanding the route may be, in order to get mentally prepared and to anticipate possible fears or hesitations. To this aim, an open atmosphere should be promoted in class, allowing teachers to spot these feelings prior to the trip, so as to act consequently and give sufficient information, creating an atmosphere of preparedness, emotional security and confidence.

Previous basic knowledge on the part of students should include adequate materials in accordance with the types of terrain, duration, conditions and time of the year; food that is adequate for physical activity in terms of energy requirements and the need for recovery; the importance of adequate hydration and the appropriateness of considering water collection points along the route; utensils, like maps and compasses, which are still necessary regardless of new technology; and, in general, knowledge of the way and the need to use any other utensils or materials that the project may include as educational resources (torches, cameras, ropes, play materials, etc.).

Prior to the trip, decisions must be made as to the pace and speed, considering previously requested information as to students' physical conditions and also as to the location and duration of stops along the way, considering aspects such as the safety, natural, cultural and/or social richness of the selected area and the possible activities to be completed there, together with necessary physical recovery.

In order for the project to be successful, the area of physical education must take responsibility for safety guidelines, anticipating the need for assistance, supervising an adequate pace and walking technique, ensuring total orientation by different means and supervising adequate food and water supplies. Teachers should have sufficient command of first aid procedures and be ready for any unexpected inconveniences along the route.

From all the previous information they have been provided with, students will be ready to take on the experience in a different natural and social environment that will open up their senses and promote an attitude for catching new sensations that teachers will enhance. In this respect, we must insist on the relevance of satisfying basic psychological needs in order to foster intrinsic motivation; maintaining a mastery climate will be crucial in experiences of this kind.

Classes in art and associated teaching methods will tackle the trips and their preliminaries from multiple perspectives, due to the wide range of aspects covered in the subjects.

The study of heritage is beneficial for a country in terms of social, cultural and identity aspects [68]. As stated by Llul [69], heritage must be analysed from a wide interdisciplinary perspective, as it is considered "the ensemble of manifestations or objects resulting from human production a society has received as a historical legacy, which are significant elements its social identity". A methodologically adequate approach to art and heritage must largely use the senses and incorporate experiential activities, especially those set away from classrooms and habitual working spaces, with outings to museums, monasteries, churches, etc., which are linked to artistic and patrimonial aspects. Thus, interdisciplinary work and integrated art, using life experiences and aesthetic enlightening, define the methodological paradigm of the present proposal, which makes use of heritage as a means to delve into its contents as well as those in art and other subject areas. As proposed by Vallès [70], three types of knowledge will be promoted, knowledge "of heritage", "through heritage" and "for heritage", focusing, this time, on artistic and cultural heritage. The first type of knowledge will foster among students the acquisition of information about stylistic, artistic and architectural data and the capacity to observe and contextualize. Learning "through heritage" will ease the comprehension of artistic education and promote an active attitude towards learning that will require learners to interpret, transform, manipulate and create. Finally, knowledge "for heritage" leads to the development of attitudes that promote appraisal and preservation.

Related to architecture, the teachers-to-be will be presented with strategies for the analysis of the built environment, which they will later integrate and apply to the proposed learning itineraries. 
Thus, the different types of buildings present along the Naranco Range will be presented. Some, such as the pre-Romanesque buildings and churches, are part of the best-known historical heritage of the area, but many other instances of traditional Asturian buildings will also be revised, to make students familiar with building and living standards from other ages: bridges, mills, snow wells, military and industrial buildings, washhouses, homes, palaces, etc. On partially urban routes, attention will also be paid to construction resulting from more recent architectural movements or periods, which are relevant to the history of the city. The proposed didactic strategy will result in comparative analyses of current architecture, based on the different architectural elements, types of space, scale, adequacy to function, and building techniques and materials. Thus, future students of those taking the proposed trips will also learn to look at architecture and see through shapes, being able to relate it to the built environment and understanding the evolution of vernacular constructions, the functionality of spaces and the use of materials.

Apart from the constructions themselves, the whole city and its urban fabric will be analyzed by students. Street sections, from the narrow winding ones in the old quarter to the broader, regular streets in the new areas will tell and configure the history of the city. This part will aim at identifying the changes produced and reflecting on the perception of the spatial experience of these changes on the part of passers-by. Students of primary education, and their pupils in the future, are not expected to gain technical knowledge on architecture or urbanism here, but rather, to progressively learn to observe what surrounds them, to analyse their perceptions of the environment and to reflect on the effects that the built or projected environment has on them.

After the classroom-bound sessions, students, organized into teams of five, will choose and take two of the proposed itineraries, one to be developed on the mountain alone and one leaving from the city. Consequently, they will all have the opportunity to observe the clear differences between the city and the rural area and learn that they are both potential educational resources, since they must be able to propose tools to make use of the didactic and leisure value of the environment, whatever its characteristics may be.

\subsection{Assessment}

\subsubsection{Student Assessment}

Field notebooks are essential tools and constitute both a learning resource and an assessment tool. Each subject area will set up some basic guidelines orienting students to collect data of what they have done, and of what they have lived and experienced, so note-taking will focus on experience, fostering a dual action: observation and introspection.

Student groups will hand in a portfolio or field notebook with an account of the itineraries taken, itemizing all relevant aspects: physical effort (heart rate records, water needs, energy use); the landscape and the physical environment (altitudes, orientation maps and data on environmental impact); artistic and architectonic elements of interest (photographs and drawings or sketches); historical and archaeological sites (geolocalization and hypothetical reconstructions); and existing settlements (data about their configuration and transcriptions of any interviews or information exchanges with inhabitants).

Together with the field notebook, each student team will propose two possible interdisciplinary activities, one per itinerary taken, to be proposed to their primary students in the future so that leisure and the contents of the three content areas in the project are integrated. The ultimate goal of the activity is for the prospective teachers to be able to design an interdisciplinary itinerary in a context different from the one they have been working in, be it in the surroundings of the school where their internship takes place or in their habitual environment. 


\subsubsection{Project Assessment}

In order to assess the viability of the project, possible changes regarding the students in terms of learning approaches and their perceptions of academic self-efficiency will be measured. Thus, prior to the implementation of the project, a questionnaire with the following two scales will be used:

- The Revised Two Factor Study Process Questionnaire (R-SPQ-2F), set up and validated by Biggs, Kember and Leung [71], and also validated by Leung and Chan [72], which assesses learning approaches (deep or superficial).

- The Questionnaire for General Academic Self-Efficiency, set up and validated by Torre [73].

Upon conclusion of the experimental period, both questionnaires will be administered, and the results obtained will be analysed with a repeated measures multivariate analysis of variance (MANOVA).

Finally, the project will be assessed by means of the model set up by Bourner, Hughes and Bourner [74], a scale that provides general estimations of group processes and results and the strategies used.

\section{Conclusions}

Students undergoing teacher training must acquire abilities such as team work and develop capacities that allow them to transmit knowledge relating to the different knowledge areas to their future students of various ages. They must be capable of generating projects and tasks with an interdisciplinary perspective, so as to integrate contents and foster significant and plural knowledge among their pupils.

The proposed itineraries are aimed at the acquisition of these capacities on the part of participants, and also at enhancing a fundamentally experiential learning model, based on experience and previous knowledge, so as to gain insight into the various subject areas involved. Interdisciplinary team work will set the basis for the development of the students' teaching skills and their future professional life.

The assessment phase of the project, during which teachers-to-be propose a route in a different area of Asturias that meets the requirements set up by university lecturers, aims to foster critical reflection on the part of student and monitor the capacity to investigate and improve their own teaching practice.

The main objective is not, therefore, for students to acquire knowledge about a given place, but for them to know educational trips as a didactic resource. Thus, in the future, they will be able to use this resource and make new proposals by themselves, as this is a "learning by doing" process.

The implementation of the present project seeks to cultivate an interdisciplinary view of teaching among teacher students, one that is far from the traditional view, which is partitioned into separate subjects. Content relating to the different areas will be treated in a holistic manner, so that a single experience relates to a diverse range of subjects and knowledge bases. In addition, the proposal opens classroom doors and takes teaching to the natural environment, to the built environment, and to the known and unknown environments beyond the school gates. Thus, students will discover a new view of their context and explore the new possibilities of teaching and learning before them. Hence, the project will present students with a new way of regarding the environment and interacting with it, taking it as an educational resource that positively contributes to reaching better living standards. Students of education are consequently expected to transmit that view to their pupils in the future, extending it to their leisure time, arousing curiosity in them and fostering autonomous learning.

Likewise, the integration of the teaching of values, such as respect for the environment, the promotion of healthy habits in leisure time and the knowledge of artistic and historical patrimony will contribute to a complete and rich education for future primary education students and the possibility of reproducing the model outside of school schedules will positively contribute to their physical and social well-being and to their cultural levels. Since compromise with society and with a 
sustainable future is a characteristic that any teacher-to-be must treasure, the present project will guide them to promote quality leisure among their pupils in the future.

The innovation project "Social Sciences, Art and Physical Activity in Leisure Environments" may be adapted so as to be implemented at any educational stage, by modifying the complexity of the routes, the distance covered and the exigencies of the trips and by adjusting the contents of the different subject areas incorporated. The proposed project may also be adapted and re-designed for implementation in the near environment of any school of teacher training by selecting elements and areas of interest in any urban and/or natural environment. Being a didactic approach that is based on coordination among teaching areas, no significant extra funding will be required, neither on the part of universities, nor for the students themselves. For the same reason, standing curricula need not be altered. Teaching hours need not be increased either, as the outings will be incorporated into students' leisure time, thus reinforcing the acquisition of content by linking it to the environment and to real experiences. This interdisciplinary approach will contribute to a better understanding of the close environment and of leisure time as a source for learning that trainee teachers will later transmit to their own students.

Author Contributions: All authors contributed to the justification and outline of the proposal and the project design. M.B.S.P.V. designed the itineraries and supervised all aspects relating to social sciences. I.F.C., I.L.M. and Y.d.C.G. contributed in the field of arts. B.S.M. made proposals as to physical education. M.B.S.P.V. and A.I.Á.G. wrote the paper, with significant input and critical revisions from the other authors. All authors read and approved the final manuscript.

Funding: This research received no external funding.

Conflicts of Interest: The authors declare no conflict of interest.

\section{References}

1. González, C. Valores sociales de la actividad físico-deportiva en la cultura del ocio. In Sociedad del Conocimiento, Ocio y Cultura: Un Enfoque Interdisciplinar, 1st ed.; Moral, M.E., Ed.; KRK: Oviedo, Spain, 2004; pp. 363-374, ISBN 84-96119-62-9.

2. Havziu, B.; Ramadani, T. Leisure Time for Secondary School Students. Int. J. Cogn. Res. Sci. Eng. Educ. 2015, $3,51-56$.

3. Baoren, S. China's Leisure Education: Problem, analysis, and solutions-A case study of college students in Hangzhou. J. Contemp. China 2010, 19, 719-733. [CrossRef]

4. Jordan, K.A.; Gagnon, R.J.; Anderson, D.M.; Pilcher, J.J. Enhancing the College Students Experience: Outcomes of a Leisure Education Program. J. Exp. Educ. 2018, 41, 90-106. [CrossRef]

5. Evans, K.E.; Hartman, C.L.; Anderson, D.M. "It's More Than a Class": Leisure Education's Influence on College Students Engagement. Innov. High. Educ. 2013, 38, 45-58. [CrossRef]

6. Hallmann, K.; Muñiz, C.; Breuer, C.; Dallmeyer, S.; Metz, M. Leisure Participation: Modelling the decisión to engage in sports and culture. J. Cult. Econ. 2017, 41, 467-487. [CrossRef]

7. Doistua, J.; Ried, A. Ocio en la naturaleza como espacio de desarrollo juvenil. Rev. Psicol. Deporte 2016, 25, 39-44.

8. Packer, J.M. Motivational Factors and the Experience of Learning in Educational Learning Settings. Ph.D. Thesis, Queensland University of Technology, Queensland, Australia, 2004.

9. Zheng, Q.; Xu, A.; Kong, D. Environmental Education, Knowledge Management and Professional Performance in eco-tourism: The Impact Relatedness. Eurasia J. Math. Sci. Technol. Educ. 2017, 13, 4679-4687. [CrossRef]

10. Fleming, D.S.; Allen, L.R.; Barcelona, R.J. Back to the future: The potential relationship between leisure and education. New Dir. Stud. Leadersh. 2011, 130, 43-57. [CrossRef] [PubMed]

11. Valovičova, L.; Siptákova, M.; Štubňa, M. Physical Terms and Leisure Time Activities. AIP Conf. Proc. 2017, 1804, 050007. [CrossRef]

12. Humberstone, B.; Prince, H.; Henderson, K.A. Routledge International Handbook of Outdoor Studies, 1st ed.; Routledge: New York, NY, USA, 2016; ISBN 978-131766651-6. 
13. Shi, Y. Explore children's outdoor play spaces of community areas in high-density cities in China: Wuhan as an example. Procedia Eng. 2017, 198, 654-682. [CrossRef]

14. Acar, H. Learning Environments for Children in Outdoor Spaces. Procedia Soc. Behav. Sci. 2014, 141, 846-853. [CrossRef]

15. Bento, G.; Dias, G. The importance of outdoor play Young children's healthy development. Porto Biomed. J. 2017, 2, 157-160. [CrossRef]

16. Wang, X.; Woolley, H.; Tang, Y.; Liu, H.; Luo, Y. Young children's and adult's perceptions of natural play spaces: A case study of Chengdu, Southwestern China. Cities 2018, 72, 173-180. [CrossRef]

17. Silverman, J.; Corneau, N. From nature deficit to outdoor exploration: Curriculum for sustainability in Vermont's public schools. J. Advent. Educ. Outdoor Learn. 2017, 17, 258-273. [CrossRef]

18. Cambil, M.E. La ciudad como recurso didáctico para la enseñanza aprendizaje del patrimonio cultural. Opción 2015, 31, 295-319.

19. Dotson, E.; Hibber, D.K.; Scott, L. Culture of Learning Cities: Connecting Leisure and Health for Lifelong Learning Communities. In Healthcare Community Synergism between Patients, Practitioners and Researchers, 1st ed.; Bryan, V.C., Bird, J.L., Eds.; IGI Global: Hearshey, PA, USA; pp. 152-175, ISBN 9781522506409.

20. Valli, R.; Valli, P.; Lähdesmäki, S. Meaningful Learning experiences in the Finnish Teacher Education. Asian J. Educ. e-Learn. 2017, 5, 27-35. [CrossRef]

21. Mullenbach, L.; Green, G.T. Can environmental education increase student-athletes' environmental behaviors? Environ. Educ. Res. 2018, 24, 427-444. [CrossRef]

22. Peñarrubia, C.; Guillén, R.; Lapetra, S. Las actividades en el medio natural en Educación Física, ¿teoría o práctica? CCD Cultura_Ciencia_Deporte 2016, 31, 27-36. [CrossRef]

23. Sousa, E.; Quintino, V.; Palhas, J.; Rodrigues, A.M.; Teixeira, J. Can Environmental Education Actions Change Public Attitudes? An Example Using the Pond Habitat and Associated Biodiversity. PLoS ONE 2016, 11, e015440. [CrossRef] [PubMed]

24. Fägerstam, E.; Blom, J. Learning biology and mathematics outdoors: Effects and attitudes in a Swedish high school context. J. Advent. Educ. Outdoor Learn. 2012, 13, 56-75. [CrossRef]

25. Richmond, D.; Sibthorp, J.; Gooking, J.; Annarella, S.; Ferri, S. Complementing classroom learning through outdoor adventure education: Out-of-school-time experiences that make a difference. J. Advent. Educ. Outdoor Learn. 2017, 18, 36-52. [CrossRef]

26. Samperiz, A.; Herrero, J. Evaluation of a summer camp environmental education program in Spain. Appl. Environ. Educ. Commun. 2018, 17, 79-90. [CrossRef]

27. Fägerstam, E. High school teachers' experience of the educational potential of outdoor teaching and learning. J. Advent. Educ. Outdoor Learn. 2014, 14, 56-81. [CrossRef]

28. Bentsen, P.; Schiperijn, J.; Jensen, F.S. Green Space as Classroom: Outdoor School Teachers' Use, Preferences and Ecostrategies. Landsc. Res. 2013, 38, 561-575. [CrossRef]

29. Owens, C.; Sotoudehnia, M.; Erickson-McGee, M. Reflections on teaching and learning for sustainability from the Cascadia Sustainability Field School. J. Geogr. High. Educ. 2015, 39, 313-327. [CrossRef]

30. Mannion, G.; Fenwick, A.; Linch, J. Place-responsive pedagogy: Learning from teachers' experiences of excursions in nature. Environ. Educ. Res. 2013, 19, 792-809. [CrossRef]

31. Ayotte-Beaudet, J.P.; Potvin, P.; Lapierre, H.G.; Glackin, M. Teaching and Learning Science Outdoors in Schools' Immediate Surroundings at K-12 Levels: A Meta-Synthesis. Eurasia J. Math. Sci. Technol. Educ. 2017, 13, 5343-5363. [CrossRef]

32. Affeldt, F.; Weitz, K.; Siol, A.; Markic, S.; Eilks, I. A Non-Formal Student Laboratory as a Place for Innovation in Education for Sustainability for All Students. Educ. Sci. 2015, 5, 238-254. [CrossRef]

33. Branden, K.V. Sustainable Education: Exploiting Students' Energy for Learning as a Renewable Resource. Sustainability 2015, 7, 5471-5487. [CrossRef]

34. Sutter, G.C.; Sperlich, T.; Worts, D.; Rivard, R.; Teather, L. Fostering Cultures of Sustainability through Community-Engaged Museums: The History and Re-Emergence of Ecomuseums in Canada and the USA. Sustainability 2016, 8, 1310. [CrossRef]

35. Cebrián, G.; Junyent, M. Competencies in Education for Sustainable Development: Exploring the Student Teachers' Views. Sustainability 2015, 7, 2768-2786. [CrossRef]

36. González, F.; López, T. Culture, tourism and World Heritage Sites. Tour. Manag. Perspect. 2017, 24, 111-116. [CrossRef] 
37. García-Hernández, M.; Calle-Vaquero, M.; Yubero, C. Cultural Heritage and Urban Tourism: Historic City Centres under Pressure. Sustainability 2017, 9, 1346. [CrossRef]

38. Ruiz-Gálvez, M.; Presa, P. A Proposal for Integration of Heritage and Tourism. Complutum 2014, 25, $229-234$. [CrossRef]

39. Pacífico, D.; Vogel, M. Archaeological sites, modern communities, and tourism. Ann. Tour. Res. 2012, 39, 1588-1611. [CrossRef]

40. Falcão, A.L.; Damásio, A.S.; Melo, R. Profile of practice, travel behaviour and motivations for geocaching. Eur. J. Tour. Res. 2017, 16, 92-107.

41. Geocaching. Available online: https://www.geocaching.com/play (accessed on 22 February 2018).

42. Ryan, R.; Deci, E.L. La Teoría de la Autodeterminación y la Facilitación de la Motivación Intrínseca, el Desarrollo Social, y el Bienestar. Am. Psychol. 2000, 55, 68-78. [CrossRef] [PubMed]

43. Trilla, J. Perspectivas educativas del ocio para el siglo XXI. Revista Proyecto Hombre 1999, 32, 8-13.

44. Orchard, G.M. Social-Emotional Benefits of Outdoor Play. Master's Thesis, University of Victoria, Victoria, BC, Canada, 2017.

45. Bochenek, M. The Influence of Author's Programme Implemented during Physical Education Classes on Tourist Activity of Pupils. Teor. Prakt. Fiz. Kult. 2015, 4, 62-64.

46. Pastor, M.J. Turismo, cultura y medio ambiente. PASOS Revista de Turismo y Patrimonio Cultural 2003, 1, 145-153. [CrossRef]

47. Arribas, H. El Pensamiento y la Biografía del Profesorado de Actividad Física en el Medio Natural: Un Estudio Multicaso en la Formación Universitaria Orientado a la Comprensión de Modelos Formativos. Ph.D. Thesis, Universidad de Valladolid, Valladolid, Spain, 2008.

48. Jarvis, P.; Newman, S.; Swiniarski, L. On 'becoming social': The importance of collaborative free play in childhood. Int. J. Play 2014, 3, 53-68. [CrossRef]

49. Sturm, R. Childhood obesity-What we can learn from existing data on societal trends, part 1. Prev. Chronic Dis. 2005, 2, A12:1-A12:9.

50. Ames, C.; Ames, R. Goal structures and motivation. Elem. Sch. J. 1984, 85, 39-52. [CrossRef]

51. Cecchini, J.A. El ejercicio físico, educación, socialización y cultura. In Respuestas a la Demanda Social de Actividad Física, 1st ed.; Zagalaz, M.L., Martínez, E., Latorre, P., Eds.; Gymnos: Madrid, Spain, 2005; pp. 31-39, ISBN 84-8013-412-7.

52. Blanton, J.E.; Oregon, E.M.; Flett, M.R.; Gould, D.R.; Pfeiffer, K.A. The Feasibility of Using Nature-Based Settings for Physical Activity Programming: Views from Urban Youth and Program Providers. Am. J. Health Educ. 2013, 44, 324-334. [CrossRef]

53. Fraile, A. Desarrollo sostenible vs. Deporte sostenible: Objetivos y principios del marco de la protección jurídica del medio ambiente. In Curso Sobre Deporte, Turismo y Medio Ambiente, 1st ed.; Rebollo, S., Ed.; Instituto Andaluz del Deporte: Málaga, Spain, 2002; pp. 49-62, ISBN 84-88718-06-3.

54. Hidalgo, M. Abandono Deportivo Escolar: Más Temprano Que Tarde. Revista Digital Educación Física y Deportes 2008, 121. Available online: http:/ / www.efdeportes.com/efd121/abandono-deportivo-escolar.htm (accessed on 21 February 2018).

55. Nuviala, A.; Tamayo, J.A.; Nuviala, R. Calidad percibida del deporte escolar como predictor del abandono deportivo en adolescentes. Rev. Int. Med. Cienc. Act. Física Deporte 2012, 12, 389-404.

56. Cecchini, J.A.; Fernandez-Río, J.; Méndez-Giménez, A. Effects of Epstein's TARGET on adolescents' intentions to be physically active and leisure-time physical activity. Health Educ. Res. 2014, 29, 485-490. [CrossRef] [PubMed]

57. Eisner, W. El arte y la Creación de la Mente. El Papel de las Artes Visuales en la Transformación de la Conciencia, 1st ed.; Paidós Ibérica: Barcelona, Spain, 2004; ISBN 84-493-1519-0.

58. González, C.; López, I.; San Pedro, J.C. Links between physical and artistic activity. J. Sport Health Res. 2013, 5, 117-130.

59. Atrio, S.; Ruiz, N.; Gómez, S. Arquitectura en la formación de formadores: Del tangram a los mosaicos nazaríes. Firmitas, utilitas y “venustas". Bordón Revista de Pedagogía 2016, 68, 43-59. [CrossRef]

60. Marczak, P. Shaping space programme as a tool for educating youth about architecture. In Proceedings of the World Multidisciplinary Civil Engineering-Architecture-Urban Planning Symposium-WMCAUS, Prague, Czech Republic, 12-16 June 2017; IOP Conference Series: Materials Science and Engineering; IOP Publishing Ltd.: Bristol, UK, 2017; Volume 245. [CrossRef] 
61. Romañá, T. Arquitectura y educación: Perspectivas y dimensiones. Rev. Esp. Pedagog. 2004, 62, $199-220$.

62. Chistensen, J.; Mygind, L.; Bentsen, P. Conceptions of place: Approaching space, children and physical activity. Child. Geogr. 2015, 13, 589-603. [CrossRef]

63. Herman, I.; Umek, M. Map use improve pupils thinking skills. Geografski Vestnik 2013, 85, 63-74.

64. European Landscape Convention. Available online: https://rm.coe.int/1680080621 (accessed on 23 May 2018).

65. Memoria-Grado en Maestro de Educación Primaria Universidad de Oviedo. Available online: http: / / calidad. uniovi.es/c/document_library /get_file?p_1_id=2535619\&folderId=2535402\&name=DLFE-58136.pdf (accessed on 10 March 2018).

66. Currículo Básico de la Educación Primaria. Available online: https:/ /www.boe.es/buscar/pdf/2014/BOEA-2014-2222-consolidado.pdf (accessed on 10 March 2018).

67. Aragón, R. Senderismo. In Actividades Físicas en el Medio Natural en la Educación Física Escolar. Cuadernos Técnicos, 1st ed.; Aguado, A., Ed.; Patronato Municipal de Deportes, Ayuntamiento de Palencia: Palencia, Spain, 2003; pp. 297-308, ISBN 84-688-2008-3.

68. Fontal, O. El patrimonio a través de la educación artística en la etapa de primaria. Arte Individuo y Sociedad 2016, 28, 105-120.

69. Llul, J. Evolución del concepto y la significación social del patrimonio cultural. Arte Individuo y Sociedad 2005, 17, 175-204.

70. Vallès, J.; Vayreda, M.; Admetlla, P.; Calbó, M.; Juanola, R. Las ciudades como museo. Arquitectura del imaginario. In Arte Infantil en Contextos Contemporáneos, 1st ed.; Belver, M., Moreno, C., Nuere, S., Eds.; Universidad Complutense: Madrid, Spain, 2005; pp. 113-126, ISBN 84-95427-92-3.

71. Biggs, J.B.; Kember, D.; Leung, D.Y.P. The Revised Two Factor Study Process Questionnaire: R-SPQ-2F. Br. J. Educ. Psychol. 2001, 71, 133-149. [CrossRef] [PubMed]

72. Leung, M.; Chan, K. Construct Validity and Psychometric Properties of the Revised Two-factor Study Process Questionnaire (R-SPQ-2F) in the Hong Kong Context. Presented at the Australian Association for Research in Education Annual Conference, Perth, Australia, 2-6 December 2001.

73. Torre, J. La Autoeficacia, la Autorregulación y los Enfoques de Aprendizaje en Estudiantes Universitarios. Ph.D. Thesis, Universidad Pontificia Comillas, Madrid, Spain, 2006.

74. Bourner, J.; Hughes, M.; Bourner, T. First-year Undergraduate Experiences of Group Project Work. Assess. Eval. High. Educ. 2001, 26, 19-39. [CrossRef] 